\title{
Transit Duration $\times$ Temperature and Fertilization of Prefinished Caladiums Affect Subsequent Growth
}

\author{
Brent K. Harbaugh \\ Gulf Coast Research and Education Center, University of Florida, 5007 \\ 60th St. E., Bradenton, FL 34203
}

Additional index words. Caladium $\times$ hortulanum, post-harvest, shipping ornamental

\begin{abstract}
Caladium $\times$ hortulanum Birdsey 'Candidum' tubers were forced in pots until at least one-half the visible sprouts were $2 \mathrm{~cm}$ above the soil surface. These prefinished plants were subjected to simulated transit durations of 2,4 , or 6 days in the dark at 12.5, 15.5, 18.5, 21.0 or $24 \mathrm{C}$. Plants were then grown for 4 weeks in a greenhouse and were either fertilized weekly with $100 \mathrm{ml}$ of a solution containing $500 \mathrm{~N}$ 218P-415K (mg-liter $\left.{ }^{-1}\right)$ or were not fertilized. Interactive effects between transit duration and temperature were significant for all measured growth responses. Transit temperature maintained for 2 days had little effect on subsequent growth and only moderate effects after 4 days. With transit duration of 6 days, an increase in temperature resulted in increased plant height, fresh weight, number of leaves, white coloration of leaves, and percent of plants judged marketable (finished) in 4 weeks. Holding at $\approx 18.5 \mathrm{C}$ was most favorable for transit durations of 4 or 6 days. Use of fertilizer during finishing improved plant growth regardless of transit conditions, but did not totally negate deleterious effects from transit conditions.
\end{abstract}

Caladium tubers produced in Florida are typically shipped to other states or countries to be forced as potted bedding or florist crops. Commercial operations with low heating costs have an interest in forcing caladiums to a sprouting stage in pots and then shipping these prefinished plants to other locations for finishing. Prefinished caladiums could be finished with other spring crops that required less heat in early stages or they could be grown in greenhouse space emptied from early bedding plant sales. For a prefinished regime to be successful, effects of shipping conditions on prefinished plants and growth during subsequent finishing need to be known. While information is available on forcing or handling tubers and finished plants (Harbaugh and Tjia, 1985; Marousky and Raulston, 1973), we found no information on transit or forcing conditions for prefinished plants. Finished caladium plants placed under simulated shipping conditions were injured with as little as $4 \mathrm{hr}$ in darkness at temperatures ranging from 1.7 to $12.8 \mathrm{C}$ (Harbaugh and Marousky, 1979). Three days at $12.8 \mathrm{C}$ resulted in $42 \%$ leaf loss. Prolonged storage of tubers at $<15.6 \mathrm{C}$ resulted in cold injury that was not alleviated by subsequent higher temperatures during forcing (Marousky, 1974). This information indicates that transit temperatures below $\approx 15.5 \mathrm{C}$ may have unfavorable effects on prefinished plants. Conover and Poole (1975) reported that higher

Received for publication 3 Aug. 1989. Florida Agricultural Experiment Station Journal Series no. R-00063. Appreciation is extended to Bates \& Sons Caladiums, Lake Placid, Fla., for supplying plant material and partial funding for this project. The cost of publishing this paper was defrayed in part by the payment of page charges. Under postal regulations, this paper therefore must be hereby marked advertisement solely to indicate this fact. nutrient levels were partly able to overcome deleterious effects of decreased plant grade, leaf color, and leaf height resulting from forcing inverted tubers. The following study was to determine the influence of simulated transit temperature and duration on the subsequent finishing of prefinished caladiums and to determine if fertilization during finishing would alleviate any stress induced during transit.

'Candidum' caladium tubers were forced by a commercial grower in $10-\mathrm{cm}(0.5$ liter $)$ pots until at least one-half the visible sprouts were $>2 \mathrm{~cm}$ above the soil surface (range $=1$ to $6.5 \mathrm{~cm}$ ). The medium was a Florida sedge peat that had not been amended with $\mathrm{N}, \mathrm{P}$, or K. Tubers had the central bud removed and one grade 1 tuber (4 to $6 \mathrm{~cm}$ diameter) was planted per pot. Prefinished plants were subjected to simulated transit durations of 2,4 , or 6 days in the dark at 12.5 , $15.5,18.5,21.0$ and $24.0 \pm 0.5 \mathrm{C}$. Plants were placed in plastic bags during transit treatments to prevent dessication and to simulate the boxed condition currently used to ship prefinished caladiums. After simulated shipping, plants were forced in a greenhouse with $18.5 \mathrm{C}$ minimum nights and $35 \mathrm{C}$ maximum days. Midday photosynthetic photon flux ranged from 600 to $800 \mu \mathrm{mol} \cdot \mathrm{s}^{-1} \cdot \mathrm{m}^{-2}$. Plants from each temperature $\times$ duration treatment were either fertilized with $100 \mathrm{ml}$ of a solution containing $500 \mathrm{~N}-218 \mathrm{P}-415 \mathrm{~K}$ $\left(\mathrm{mg} \cdot\right.$ liter $\left.^{-1}\right)$ once a week or were not fertilized. The experimental design was a 5 (temperature) $\times 3$ (transit duration) $\times 2$ (fertilization regime) factorial in a split-plot design with temperature as the main plot. The experiment was replicated three times in time, with growth chamber temperatures randomized for each replication. There were 10 plants per experimental unit. Data on length of longest sprout and number of sprouts $>3$ $\mathrm{cm}$ were taken when the last plants were removed from the growth chambers (6 days). Data taken 4 weeks after transit conditions included plant height, plant width, number of leaves per plant, above-ground plant fresh weight, number of plants judged marketable, and a subjective rating on leaf coloration (1 $=$ leaves mostly green with $<10 \%$ white; 3 $=$ leaves with $\approx 50 \%$ white; $5=$ leaves mostly white, except the veins).

Interactive effects between transit duration and temperature were significant for all measured growth responses. Interactive effects of fertilization with transit temperature and/ or transit duration were not significant. Thus, means in Table 1 are from averages of fertilized and unfertilized plants. With 2 days of transit, the length of the tallest sprout and the number of sprouts $>3 \mathrm{~cm}$ increased only slightly as temperature increased. Effects of transit temperature on plants subsequently forced in the greenhouse for 4 weeks were not detected. With 4 days of simulated transit, sprout elongation and final plant height increased moderately as temperature increased. Response trends to temperature for finished plant characteristics were similar to those resulting from 6 days of transit, but trends were moderate and not significant at $P=0.05$. By 6 days of transit, linear or quadratic responses to temperature were evident for initial sprout lengths and all finished plant characteristics.

In general, the greatest differences in responses to temperature reflected in finished plant characteristics were at the lower temperatures, i.e., between 12.5 to $15.5 \mathrm{C}$ and 15.5 to $18.5 \mathrm{C}$ (Table 1). Higher transit temperatures had a greater influence on sprout lengths. Some sprouts were extremely long at 21.0 and $24.0 \mathrm{C}$; when leaves unfurled, they were too tall for a $10-\mathrm{cm}$ pot. Caladium shoots twist and bend if adequate space is not available for shoots to elongate upright, as would be the case if plants were shipped in a box. As leaves unfurl, the petioles remain deformed and unattractive on finished plants. Taken together, these results indicate that transit temperatures $\approx 18.5 \mathrm{C}$ would be desirable for shipping prefinished caladiums. Lower temperatures resulted in less-desirable and less-marketable plants after 4 weeks in the greenhouse, especially following 6 days of transit. Some of the plants from 6-day transit durations at $12.5 \mathrm{C}$ were not marketable after 6 to 8 weeks, displaying typical cold-injury symptoms of slow growth and small, chlorotic leaves. Temperatures $>18.5 \mathrm{C}$ resulted in some plants with distorted shoots and with leaves too tall for a $10-\mathrm{cm}$ pot. When held at $18.5 \mathrm{C}, \approx 90 \%$ of the fertilized plants from 4 or 6 days of transit were marketable after 4 weeks in the greenhouse.

'Candidum' is the most commonly produced white cultivar, yet the partial or even total loss of white leaf color has caused production losses in certain situations over the years. These results indicated that cold temperatures during transit resulted in finished plants with fewer white leaves.

Main effect means for fertilization treat- 
Table 1. Effects of transit temperature for 2,4, or 6 days on sprouting of prefinished caladiums during simulated shipping and subsequent growth during 4 weeks of finishing in a greenhouse. ${ }^{2}$

\begin{tabular}{|c|c|c|c|c|c|c|c|c|}
\hline \multirow[b]{2}{*}{$\begin{array}{l}\text { Transit } \\
\text { temp. } \\
\left({ }^{\circ} \mathrm{C}\right)\end{array}$} & \multicolumn{2}{|c|}{$\begin{array}{c}\text { Immediate } \\
\text { effects }^{y}\end{array}$} & \multicolumn{6}{|c|}{ Subsequent effects } \\
\hline & $\begin{array}{l}\text { Sprout } \\
\text { length } \\
(\mathrm{cm})\end{array}$ & $\begin{array}{c}\text { Sprouts } \\
3 \mathrm{~cm} \\
\text { (No.) }\end{array}$ & $\begin{array}{l}\text { Plant } \\
\text { height } \\
(\mathrm{cm})\end{array}$ & $\begin{array}{l}\text { Plant } \\
\text { width } \\
\text { (cm) }\end{array}$ & $\begin{array}{l}\text { Leaves/ } \\
\text { plant } \\
\text { (No.) }\end{array}$ & $\begin{array}{c}\text { Plant } \\
\text { fresh } \\
\text { wt }(g)\end{array}$ & $\begin{array}{c}\text { Marketable } \\
\text { plants } \\
(\%)\end{array}$ & $\begin{array}{l}\text { White } \\
\text { color }^{\mathrm{x}} \\
\text { (rating) }\end{array}$ \\
\hline \multicolumn{9}{|c|}{ Two days of transit } \\
\hline 12.5 & . 8.1 & 2.5 & 22 & 31 & 8 & 39 & 47 & 4.2 \\
\hline 15.5 & 8.1 & 2.5 & 21 & 31 & 7 & 41 & 55 & 4.0 \\
\hline 18.5 & 9.0 & 2.9 & 23 & 32 & 8 & 40 & 53 & 4.3 \\
\hline 21.0 & 10.2 & 3.1 & 22 & 32 & 8 & 41 & 53 & 4.3 \\
\hline 24.0 & 11.4 & 3.9 & 23 & 32 & 8 & 41 & 53 & 4.7 \\
\hline Linearw & 0.01 & 0.01 & NS & NS & NS & NS & NS & NS \\
\hline Quadratic & NS & NS & NS & NS & NS & NS & NS & NS \\
\hline \multicolumn{9}{|c|}{ Four days of transit } \\
\hline 12.5 & 7.1 & 1.8 & 20 & 30 & 7 & 36 & 45 & 3.9 \\
\hline 15.5 & 7.8 & 2.5 & 22 & 30 & 8 & 38 & 63 & 4.1 \\
\hline 18.5 & 10.1 & 3.0 & 21 & 31 & 8 & 38 & 56 & 4.0 \\
\hline 21.0 & 10.6 & 4.1 & 22 & 31 & 8 & 40 & 62 & 4.5 \\
\hline 24.0 & 13.1 & 4.9 & 22 & 32 & 8 & 43 & 61 & 4.4 \\
\hline Linear & 0.01 & 0.01 & 0.08 & NS & NS & NS & NS & NS \\
\hline Quadratic & NS & NS & NS & NS & NS & NS & NS & NS \\
\hline \multicolumn{9}{|c|}{ Six days of transit } \\
\hline 12.5 & 6.5 & 2.1 & 18 & 27 & 5 & 29 & 30 & 3.0 \\
\hline 15.5 & 8.7 & 2.8 & 21 & 30 & 7 & 40 & 50 & 3.8 \\
\hline 18.5 & 11.9 & 3.9 & 22 & 31 & 8 & 40 & 62 & 4.0 \\
\hline 21.0 & 14.1 & 4.8 & 22 & 31 & 8 & 41 & 66 & 4.4 \\
\hline 24.0 & 16.4 & 6.2 & 23 & 31 & 8 & 44 & 62 & 4.4 \\
\hline Linear & 0.01 & 0.01 & 0.01 & 0.01 & 0.01 & 0.01 & 0.07 & 0.01 \\
\hline Quadratic & NS & NS & NS & 0.09 & 0.10 & NS & NS & NS \\
\hline
\end{tabular}

${ }^{2}$ Means are from 60 plants, three replications of 10-plant experimental units averaged over two fertilization treatments.

'Data on length of longest sprout and sprouts $>3 \mathrm{~cm}$ taken after transit treatment, and other data taken after 4 weeks of finishing in the greenhouse.

${ }^{x}$ Subjective leaf color rating with $1=$ leaves mostly green with $<10 \%$ white coloration, $3=$ leaves with $\approx 50 \%$ white coloration, $5=$ leaves white except for the veins.

"Significance levels given, except NS $=P>0.10$.

Table 2. Influence of fertilization after simulated transit on growth of prefinished caladiums.

\begin{tabular}{|c|c|c|c|c|c|c|}
\hline Fertilization ${ }^{2}$ & $\begin{array}{l}\text { Plant } \\
\text { height } \\
(\mathrm{cm})\end{array}$ & $\begin{array}{l}\text { Plant } \\
\text { width } \\
\text { (cm) }\end{array}$ & $\begin{array}{c}\text { Leaves/ } \\
\text { plant } \\
\text { (No.) }\end{array}$ & $\begin{array}{c}\text { Plant } \\
\text { fresh } \\
\text { wt (g) }\end{array}$ & $\begin{array}{c}\text { Markctable } \\
\text { plants } \\
(\%)\end{array}$ & $\begin{array}{l}\text { White } \\
\text { color }^{y} \\
\text { (rating) }\end{array}$ \\
\hline Yes & 23 & 33 & 9 & 48 & 80 & 4.3 \\
\hline & 21 & 29 & 6 & 31 & 27 & 4.0 \\
\hline Tukey's HSD 5\% & 0.5 & 0.7 & 0.5 & 2.2 & 7.8 & 0.26 \\
\hline
\end{tabular}

${ }^{2}$ Plants were fertilized with $100 \mathrm{ml}$ of a solution containing $500 \mathrm{~N}-218 \mathrm{P}-415 \mathrm{~K}\left(\mathrm{mg} \cdot \mathrm{liter}^{-1}\right)$ once a week for 4 weeks or were not fertilized. Means are from 450 plants, three replications of 10-plant experimental units averaged over three transit duration treatments and five transit temperature treatments.

Subjective leaf color rating with $1=$ leaves mostly green with $<10 \%$ white coloration, $3=$ leaves with $\approx 50 \%$ white coloration, $5=$ leaves white except for the veins. ments are averaged over transit duration and temperature treatments, since interactions were not significant (Table 2). Only small increases in plant height $(2 \mathrm{~cm})$, plant width $(4 \mathrm{~cm})$, and color rating resulted from fertilization, but the number of leaves per plant and plant fresh weight increased $\approx 50 \%$, and the number -of plants judged marketable increased 200'\% due to fertilization. Although fertilization improved finished plant characteristics regardless of transit conditions and would thus be beneficial, fertilization was not able to entirely negate damage done by the simulated transit conditions. For example, plant fresh weights were 24, 28,33,35, and $36 \mathrm{~g}$ for unfertilized plants and 34,44 , 48,47 and $53 \mathrm{~g}$ for fertilized plants following 6 days of holding at 12.5, 15.5, 18.5, 21.0 and $24.0 \mathrm{C}$, respectively. Fertilized plants weighed more than unfertilized plants from each transit temperature treatment, but fertilized plants from the $24.0 \mathrm{C}$ treatment weighed $50 \%$ more than fertilized plants from the $12.5 \mathrm{C}$ transit treatment.

\section{Literature Cited}

Conover, C.A. and R.T. Poole, 1975. Influence of fertilizer level, apical bud removal, and tuber orientation on forcing of Caladium bicolor. HortScience 10(3):226-227.

Harbaugh, B.K. and B.O. Tjia. 1985. Commercial forcing of caladiuma. Fla. Coop. Ext. Serv. Cir. 621 .

Harbaugh, B.K. and F.J. Marousky. 1979. Warm environment-key to forcing caladiums. Florists' Rev. 163:64-68.

Marousky, F.J. 1974. Influence of curing and low temperature during storage on subsequent sprouting of caladium tubers. Proc. Fla. State Hort. Soc. 87:426-428.

Marousky, F.J. and J.C. Raulston. 1973. Influence of temperature and duration of curing, storage, shipping and forcing periods on caladium growth. Proc. Fla. State Hort. Soc. 86:363368. 